\title{
IMPRESSION INTELLECTUAL CAPITAL AND RISK PROFILE ON PROFITABILITY
}

${ }^{123}$ Neny Tri Indrianasari, Khoirul Ifa, Muhamad Ali

Departement of Accountinng, STIE Widya Gama Lumajang ${ }^{12}$

Universitas Hamzanwadi Lombok Timur ${ }^{3}$

Email: indriana85@gmail.com

\section{A R T I C L E IN F O}

Date of entry:

17 Januari 2020

Revision Date:

19 February 2020

Date Received:

8 June 2020

\begin{abstract}
A B S T R A C T
The importance of intellectual capital aspects for companies makes this topic interesting to be researched today, especially related to the contribution of IC in encouraging company performance. Profitability is an appropriate benchmark in measuring the performance of a bank. One measure of profitability used is Return on Equity (ROE). ROE is used to measure the effectiveness of a company in generating profits by utilizing the equity it has. This study aims to determine the Impression of Intellectual Capital and Risk Profile on Profitability of BPR Syariah in East Java Province. This type of research used in this research is descriptive research with a quantitative approach. The population used in this study were all Sharia Rural Banks (BPRS) of East Java Province which were recorded in the Financial Services Authority (OJK) for the selected period of 2015-2018 with a total population of 26 banks. The sample in this study was selected by purposive sampling. This study concludes that the NPF ratio has no effect on ROE. Except for Intellectual Capital and FDR it has a significant influence on ROE.
\end{abstract}

Keywords: Profitability, Intellectual Capital and Risk Profile

Cite this as: Indrianasari. N. T. (2020). IMPRESSION INTELLECTUAL CAPITAL AND RISK PROFILE ON PROFITABILITY. Assets : Jurnal Ilmiah Ilmu Akuntansi, Keuangan dan Pajak, 4(2), 101-108

\section{INTRODUCTION}

Banking performance in the modern era is not only measured from the financial aspect, but also from the non-financial aspects, such as; corporate governance, intangible assets s, Economic Value Added (EVA), and other performance measures (Ulum, 2013). In the banking entity, management responsibility is not only seen from certain ratios and accounting disclosures, but also pay attention to non-financial aspects, one of which is disclosure and application. intellectual capital ( IC) (Ulum, 2013). The importance of aspects intellectual capital for companies making this topic interesting to study today, especially related to the contribution of IC in encouraging company performance (Ulum, 2013). IC performance measurements in many studies have focused on performance measures of intangible assets (intangible assets) as; goodwill, acquisition costs, 
patents, trade mark, and royalty. This is because IC is considered a strategic aspect that is able to lead companies to obtain and maintain competitive advantage ( competitive advantage) sustainable ( sustainable) (Wang and Chang, 2005). Therefore, performance measurement intellectual capital making the company able to monitor which parts need to be improved in the IC aspect, with the aim of the company being able to generate greater profits in the future (Kamukama, Ahiauzu, \& Ntayi, 2011).

Relationship between intellectual capital the financial performance has been proven empirically by (Ulum, 2013) showing that there is a positive influence of IC (VAIC TM) on the company's financial performance; IC (VAIC TM) also has a positive effect on the company's future financial performance; and that the average IC growth (the rate of growth of a company's IC - ROGIC) no effect on the company's financial performance in the future. Furthermore Pratiwi (2014) shows that the independent variable IC (Human Capital Efficiency (HCE), Capital Employed Efficiency (CEE) and Structural Capital Efficiency ( SCE)) together affect ROA and ROE. While partially for Model 1 only HCE has a positive effect on ROA. As for model 2, only HCE and CEE have a positive effect on ROE. Temporarily (Hermawan \& Mardiyanti, 2016shows that Intellectual Capital (VAIC) affects the company's financial performance Return on Assets (ROA), Return on Equity (ROE), Earnings per Share (EPS). While the results of the study (Maditinos, Chatzoudes, Tsairidis, \& Theriou,2011) examined the relationship between Intellectual Capital with respect to market value and financial performance of 4 types of companies found in Greece. The results showed that only HCE (Human Capital Efficiency) which is a component of Intellectual Capital which has a significant relationship with ROE.

Profitability is an appropriate benchmark in measuring the performance of a bank. One measure of profitability used is Return on Equity (ROE). ROE is used to measure the effectiveness of a company in generating profits by utilizing the equity it has. Return on Equity constitutes return on yield or equity whose amount is expressed as a parameter and is obtained on investment in the company's ordinary shares for a certain period of time (Mulyadi, 2006). The higher this ratio, the greater the rate of refund given to shareholders. The ROE standard according to PBI No.6 / 10 / PBI / 2004 is 5\% -12.5\%. The greater the ROE, the greater the level of profits obtained by banks that have an impact on the better the bank's position in terms of capital management. (Kuncoro and Suhardjono, 2011)

Non Performing Financing (NPF) is a financial ratio that shows the financing risks faced by banks due to the provision of financing and investment bank funds in different portfolios. This financing risk can occur due to failure or inability of the customer to return the loan amount received from the bank and the profit sharing in accordance with the scheduled period. NPF in Islamic banks based on OJK data has exceeded the maximum limit of 5\% with ideally below 5\%. Non Performing Financing (NPF) in Kapolo T Fundo's research, Ayeni R Kolade, and Oke M Ojo (2012) showed a negative influence on profitability.

Financing to Deposit Ratio (FDR) which is analogous to Loan to Deposit Ratio in conventional banks is a comparison between financing provided by banks with third party funds successfully collected by banks. The lower FDR shows the lack of effectiveness of banks in channeling credit. If the FDR or LDR ratio for most BUS is below the $100 \%$ standard set by Bank Indonesia. Then the profit earned by the bank will increase (assuming the bank is able to distribute credit effectively).

Based on resource based theory, intellectual capital owned by the company is able to create a competitive advantage of the company so that it can improve company performance for the better, one of which is to increase company profits. With the use intellectual capital It is expected to increase sales and use company resources efficiently and economically which can make an increase in company profits. Research conducted by (Wijayani, 2017) proves that variables Intellectual Capital significant positive effect on ROE. This condition occurs because of 
Intellectual Capital increase, the company has used its capital more effectively to increase human resources, so that employee performance results in increased profits.

Non Performing Financing (NPF) is a ratio used to measure risk to loans channeled by comparing problem financing with the amount of financing channeled. NPF is intended for Islamic banks, while NPL (Non Performing Loans) intended for commercial banks. The higher this ratio, the worse the quality of financing a bank (Abduh \& Azmi Omar, 2012). The high NPF shows that the bank is not professional in managing its financing, so this gives an indication that the level of risk for financing the bank is quite high in line with the NPF faced (Pratiwi, 2016). Because financing is the largest sector in contributing to bank revenue, so the higher the problematic financing at Sharia Commercial Banks, the income received by the bank will decrease, this results in a decrease in profitability of Islamic Commercial Banks.

Financing To Deposit Ratio (FDR) reflects the ability of banks to distribute funds to parties who need capital (Kasmir, 2014a). FDR illustrates the ratio between the amount of loans or financing provided to customers with the amount of funds raised by Islamic banks. High or low FDR ratio shows the level of bank liquidity (Pramudhito, 2014). Bank Indonesia has set an ideal FDR ranging from $78 \%$ to $100 \%$. The higher the funds channeled by banks in the form of financing, the higher the ability of banks to provide loans. This has an impact on increasing revenue,so that the benefits of Islamic banking are increasing. However, if the financing disbursed by the bank is low, it can be said that the level of bank liquidity is too high so this causes pressure on bank revenues in the form of high costs of maintaining idle cash ( idle money) (Rahum, 2008). According to research conducted by Irhamsyah (2010) concluded that FDR has a significant positive effect on ROE. This opinion is supported by Rafelia (2013) who concluded that profitability (Return On Equity) banks are significantly influenced by one of the variables, namely FDR.

Based on several theoretical considerations that raise the importance intellectual capital in a company, especially in company development and also about existence intellectual capital which is considered important in the disclosure of financial statements, researchers get the idea to follow up on themed research Intellectual Capital and Risk Profile to the BPR Syariah Profitability.

\section{METHODS}

This type of research uses a descriptive quantitative approach to analyze the measured ratios. This method aims to describe the data collected systematically and accurately, so that by using this method, it is expected to be able to clearly describe the state of the impression Intellectual Capital and Risk Profile towards profitability. The object of this research is the Sharia Rural Bank in the East Java region for 4 years, from 2015 to 2018. The population used in this study is all Sharia Rural Bank (BPRS) of East Java Province which is recorded in the Financial Services Authority (OJK) for the selected period of 2015-2018 with a population of 30 banks. The sample in this study was chosen individually purposive sampling namely as many as 15 banks. The dependent variable in this study is the ratio Intellectual Capital and Risk Profile. While the independent variable in this study is profitability. Therefore the model that will be used in this study is $y=\alpha+b_{1} x_{1}+b_{2} x_{2}+b_{3} x_{3}+\cdots+b_{n} x_{n}$. T test is used to determine the existence of a significant effect of the ratio Intellectual Capital and Risk Profile towards profitability. Whereas the F test is used to determine the effect of the ratio simultaneously Intellectual Capital and Risk Profile towards Profitablitas. And to explain variance profitability proportion by Intellectual Capital and Risk Profile coefficient is used determination (R2). Test the Classical assumptions, which consists of Normality Test, Autocorrelation, and Heteroscedasticity is done before Data analysis was performed. 


\section{RESULTS AND DISCUSSION}

Normality test is used to determine whether the data used are normally distributed. In this study, the normal distribution is used in the residual regression model where the model is said to be good if the residuals of the model are normally distributed and vice versa. Normality test is done by looking normal probability plot on the output SPSS, if the data distribution values are located around a diagonal straight line then the normality requirements are met. The PP plot plot for the regression equation states that the results of normality test data indicate a normal graph pattern where the points are not far from the diagonal line, this means that the regression model has a normal distribution. Multicollinearity test is used to test whether in the regression model a correlation between independent variables is found. Multicollinearity can be seen from the value of tolerance and value variance inflation factor (VIF). Where is said to occur multicollinearity if the VIF value $\geq 10$. Whereas if the VIF value $\leq 10$ means that there is no multicollinearity. all independent variables have a VIF value of less than 10 in both regression models. So it can be concluded that there is no multicollinearity between independent variables in the regression model.

The autocorrelation test aims to test whether in a linear regression model there is a correlation between confounding errors in period $t$ and errors in period $t-1$ (previous). If there is a correlation, it is called autocorrelation. A good regression model is regression that is free of autocorrelation. Autocorrelation needs to be tested on a regression whose data is time series, or based on periodic times such as monthly, yearly, and so on. Detecting autocorrelation in the regression model can use quantities Durbin-Watson ( DW) with the following conditions: a. If du $<\mathrm{d}<4-\mathrm{du}$, then $\mathrm{H} 0$ is accepted, meaning that there is no autocorrelation in the regression model. b. If $0<\mathrm{d}<\mathrm{dl}$ or 4 $\mathrm{dl}<\mathrm{d}<4$, then $\mathrm{H} 1$ is accepted, meaning that there is an autocorrelation in the regression model. c. If $\mathrm{dl} \leq \mathrm{d} \leq \mathrm{du}$ or $4-\mathrm{du} \leq \mathrm{d} \leq 4-\mathrm{dl}$, then the test results are conclusive, so it cannot be determined there autocorrelation or not. Before analyzing the results of the Durbin Watson test, first determine the lower limit (dl) and upper limit (du). The autocorrelation test results using the Durbin-Watsion (DW) test above indicate a value of 1.554. The dU value is 1.6889 and $\mathrm{dL}$ is 1.4797 and the DW value is between the dU boundary and the $\mathrm{dL}$ or DW $<4$-dU limit, which is $1.554<2.3111$ so that no autocorrelation occurs or is free from autocorrelation. Heterokedastisitas means that the variable variance is not the same for all observations. Means heterokedastisitas is a condition where the data contains data elements cross section and have different variants. To find out whether the data used in the regression model meets the assumption that heterokedasticity does not occur is to look at the SPSS output on scatterplot dependent variable, if the data distribution values are not clear and the points spread above and below the number 0 on the $\mathrm{Y}$ axis, then heterocedasticity does not occur

Based on output scatterplot above, it appears that the points spread and do not form certain patterns clearly. So it can be concluded that there is no heteroscedasticity problem that is the inequality of variance from residuals to observations to other observations. Mudrajad Kuncoro (2007) states that the t test is used to determine the effect of the independent variable on the dependent variable partially tested significantly. The following criteria for this test: The level of significance used is 5 percent, in other words if $\mathrm{P}$ (probability)> 0.05 then it is declared insignificant. T test results on the IC, NPF, FDR to ROE variables are summarized in table 4.3 above. Based on the results of the t test showed that IC and FDR affect ROE, this is because the significance value of IC and FDR is less than 0.05 namely 0.001 and 0,000 . While the NPF ratio has no effect on ROE, this is because the significance value of the NPF is more than 0.05 , namely 0.210 .

H1 Influence Intellectual Capital to Return On Equity (ROE) Research findings found that Intellectual Capital effect on Return On Equity (SROE). This shows that the higher Intellectual Capital, then ROE is increasing. This condition occurs because of intellectual capital the more 
increasing, the company has used its capital more effectively to improve the ability of human resources, so that employee performance to generate profits has increased. Based on theory resource-based theory, the company will excel in business competition and get good financial performance by using its capital for the benefit of improving human resources which is one of the company's capital. Intellectual capital is believed to play an important role in increasing company value and financial performance (ROE). These results support the research of Fajarini and Firmansyah (2012), proving that Intellectual Capital positive effect on ROE. The higher it is Intellectual Capital, then ROE is increasing. But the results of this study are not in line with the research of Kuryanto and Syafruddin (2008), and Wijayanti (2012) proving that Intellectual Capital no significant effect on ROE.

H2 Influence Non Performing Financing to Return On Equity (ROE). Research findings found that Non Performing Financing ( NPF) has no effect on Return on Equity (ROE). This shows that the increase or decrease in the NPF ratio has no effect on Return On Equity (ROE). So the hypothesis states that Non Performing Financing (NPF) partial effect on Return On Equity (ROE) cannot be accepted. Poor credit quality will increase risk, especially if lending is done without using the principle of prudence and expansion in lending that is less controlled so that banks will bear greater risks as well. The risk is in the form of difficulties in returning credit by debtors which, if the amount is large enough, can affect banking performance. The presence of non-performing loans has caused many loans to be disbursed. The results of this study are consistent with research conducted by Varadigna and Suhadak (2017), which states that Non Performing Loans (NPL) has no significant effect on Return On Equity ( ROE). In contrast to research conducted by Saputri and Oetomo (2016) and Damayanti and Musadieq (2017), which states that Non Performing Loans (NPL) significant effect on Return On Equity (ROE)

H3 Influence Financing to Deposit Ratio to Return On Equity (ROE). Research findings found that Financing to Deposit Ratio (FDR) effect on Return on Equity (ROE). This means the influence of FDR on ROE can be caused by the amount of financing provided (PYD) and third party funds (DPK) in Islamic banking including Islamic commercial banks (BUS), Islamic business units (UUS), and Islamic people's financing banks (BPRS) continue to increase. The FDR value indicates that Islamic banks have good liquidity to expand financing because they are supported by sufficient funding sources. This means that the higher the FDR, the lower the ROE generated. Banks must also follow the standards of Bank Indonesia, which calls for banking FDRs to be above $80 \%$ to carry out the banking intermediary function. The higher the FDR with a maximum of $110 \%$ (LPP, 2009), the higher the banking revenue will be. The results of this study contradict the previous hypothesis which states that FDR has a positive effect on ROE. The results of this study indicate that the higher the FDR, the ROE of a bank will decrease, where each FDR increase of $1 \%$ will result in a decrease in ROE of $0.037 \%$. This result is not in accordance with Farrashita Aulia's research which shows that the FDR variable has a positive effect on ROE which states that a high FDR tends to have a higher ROE as well. The results of this study differ from studies conducted by Ayuni and Oetomo (2017) which state that Loan To Deposit Ratio (LDR) has no significant effect on Return On Equity ( ROE). These results are different consistent with research conducted by Saputri and Oetomo (2016) which states that Loan To Deposit Ratio (LDR) effect on Return On Equity (ROE).

\section{CONCLUSION}

Based on the results of testing the hypothesis and referring to the formulation and objectives of this study, the following conclusions can be drawn. The research results found that Intellectual Capital effect on Return On Equity (ROE). This shows that the higher Intellectual Capital, then ROE is increasing. This condition occurs because of intellectual capital the more increasing, the company has used its capital more effectively to improve the ability of human resources, so that employee performance to generate profits has increased. Research findings found that Non 
Performing Financing (NPF) has no effect on Return On Equity (ROE). This shows that the increase or decrease in the NPF ratio has no effect on Return On Equity (ROE). Research findings found that Financing to Deposit Ratio (FDR) effect on Return On Equity ( ROE). This means the influence of FDR on ROE can be caused by the amount of financing provided (PYD) and third party funds (DPK) in Islamic banking including Islamic commercial banks (BUS), Islamic business units (UUS), and Islamic people's financing banks (BPRS) continue to increase.

The results of this study indicate Intellectual Capital significant positive effect on ROE. This has implications for the future that banks in implementing human resources that manage company capital will be competent people who are able to manage capital and maintain investor confidence in the company. The management of Islamic BPR is able to increase the FDR ratio in channeling financing effectively, reducing the NPF ratio in financing problems that occur. For users of financial statements in making decisions to invest, investors can see the FDR, NPF, and IC that have an influence on increasing profitability which is reflected through ROE to see a picture of how the company's condition can be profitable or not as an investment medium. Because the greater the ROE, investors will be more interested in investing.

Limitations in this study include the following limitations: first the sample chosen was only the BPR Syariah of East Java Province. So it is necessary to expand the sample not only to the Province of East Java alone. Variables in other risk profiles have not been studied. The main reason for not including other risk profile variables is lack of access to data, thus, certain interesting elements cannot be investigated. This research only uses a period of 3 years. By increasing the observation period, more accurate results will be obtained..

\section{REFERENCE}

Abduh, M., \& Azmi Omar, M. (2012). Islamic banking and economic growth: the Indonesian experience. International Journal of Islamic and Middle Eastern Finance and Management. https://doi.org/10.1108/17538391211216811

Almunawwaroh, M., \& Marliana, R. (2018). Pengaruh Car,Npf Dan Fdr Terhadap Profitabilitas Bank Syariah Di Indonesia. Amwaluna: Jurnal Ekonomi Dan Keuangan Syariah. Https://Doi.Org/10.29313/Amwaluna.V2i1.3156

Ascarya, A., \& Yumanita, D. (2007). Mencari Solusi Rendahnya Pembiayaan Bagi Hasil Di Perbankan Syariah Indonesia. Buletin Ekonomi Moneter Dan Perbankan. Https://Doi.Org/10.21098/Bemp.V8i1.127

Bank Indonesia. (1998). Undang-Undang Nomor 10 Tahun 1998 Tentang Perbankan. UndangUndang Nomor 10 Tahun 1998 Tentang Perbankan. Https://Doi.Org/10.1007/S13398-0140173-7.2

Bank Indonesia. (2011). Peraturan Bank Indonesia Nomor: 13/1/Pbi/2011 Tentang Penilaian Tingkat Kesehatan Bank Umum. Peraturan Bank Indonesia.

Dendawijaya, L. (2005). Manajamen Lembaga Keuangan. Jurnal Akuntansi.

Hakiim, N. (2018). Pengaruh Internal Capital Adequency Ratio (Car), Financing To Deposit Ratio (Fdr), Dan Biaya Operasional Per Pendapatan Operasional (Bopo) Dalam Peningkatan Profitabilitas Industri Bank Syariah Di Indonesia. Mega Aktiva: Jurnal Ekonomi Dan Manajemen. Https://Doi.Org/10.32833/Majem.V7i1.55

Harahap, S. S. (2009). Analisa Kritis Laporan Keuangan. In Teori Akuntansi. https://doi.org/www.rajagrafindo.com

Hardina, L., Sasongko, N., \& Setiawati, E. (2019). Pengaruh Islamicity Performance Index Terhadap Profitabilitas Dengan Intellectual Capital Sebagai Variabel Moderating Pada Perbankan Syariah Di Indonesia. Urecol.

Hermawan, S., \& Mardiyanti, U. I. (2016). Intellectual Capital Dan Kinerja Keuangan Perusahaan Manufaktur High Ic Intensive. Benefit: Jurnal Manajemen Dan Bisnis. https://doi.org/10.23917/benefit.v1i1.2367 
Hermina, R., \& Suprianto, E. (2014). Analisis Pengaruh Car, Npl, Ldr Dan Bopo Terhadap Profitabilitas (Roe) Pada Bank Umum Syariah. Jurnal Akuntansi Indonesia.

Ilham, R., Wardana, P., \& Widyarti, E. T. (2015). Analisis Pengaruh CAR, FDR, NPF, BOPO, Dan Size Terhadap Profitabilitas Pada Bank Umum Syariah Di Indonesia (Studi Kasus Pada Bank Umum Syariah Di Indonesia Periode 2011-2014). Diponegoro Journal Ofmanagement.

Indonesia, P. R. (2008). Uu Nomor 21 Tahun 2008 Tentang Perbankan Syariah. Undang Undang Republik Indonesia. Https://Doi.Org/10.1017/Cbo9781107415324.004

Kamukama, N., Ahiauzu, A., \& Ntayi, J. M. (2011). Competitive advantage: Mediator of intellectual capital and performance. Journal of Intellectual Capital. https://doi.org/10.1108/14691931111097953

Kasmir. (2002). Analisis tingkat kecukupan modal dan loan to deposit ratio terhadap profitabilitas. Dasar-Dasar Perbankan.

Kasmir. (2014). Laporan Keuangan Bank. In Manajemen Perbankan.

Kasmir. (2014a). Bank dan Lembaga Kuangan Lainnya. In PT. Raja Grafindo Persada jakarta.

Kasmir. (2014b). Laporan Keuangan Bank. In Manajemen Perbankan.

Kuncoro, Mudrajad. (2010). Metode Kuantitatif: Teori Dan Aplikasi Untuk Bisnis Dan Ekonomi. In System.

Latumaerissa, R. J. (1999). Mengenal Aspek-Aspek Operasi Bank Umum. In Jakarta: Bumi Aksara. Https://Doi.Org/10.1002/Pauz.200790112

Lukman Dendawijaya. (2005). Manajamen Lembaga Keuangan. Jurnal Akuntansi.

Maditinos, D., Chatzoudes, D., Tsairidis, C., \& Theriou, G. (2011). The impact of intellectual capital on firms' market value and financial performance. Journal of Intellectual Capital. https://doi.org/10.1108/14691931111097944

Mondal, A., \& Ghosh, S. K. (2012). Intellectual capital and financial performance of Indian banks. Journal of Intellectual Capital. https://doi.org/10.1108/14691931211276115

Otoritas Jasa Keuangan. (2018). Statistik Perbankan Indonesia 2017. Ojk.

Pengaruh Pembiayaan Bagi Hasil, Pembiayaan Jual Beli, Financing To Deposit Ratio (Fdr) Dan Non Performing Financing (Npf) Terhadap Profitabilitas Bank Umum Syariah Di Indonesia. (2014). Accounting Analysis Journal. Https://Doi.Org/10.15294/Aaj.V3i4.4208

Prasetiono, F. A. (2016). Pengaruh CAR , FDR , NPF , Dan BOPO Terhadap Profitabilitas ( Return On Equity ) ( Studi Empiris pada Bank Umum Syariah di Indonesia Periode Tahun 2009-2013 ). Diponegoro Journal of Management.

Pratiwi, A. (2016). Pengaruh Kualitas Penerapan Good Corporate Governance (GCG) Terhadap Kinerja Keuangan Pada Bank Umum Syariah Di Indonesia (Periode 2010-2015). Al-Tijary - Jurnal Ekonomi Dan Bisnis Islam. https://doi.org/10.21093/at.v2i1.610

Refmasari, V. A., \& Setiawan, N. (2014). Penilaian Tingkat Kesehatan Bank Umum Menggunakan Metode RGEC Dengan Cakupan Risk Profile, Earnings, dan Capital Pada Bank Pembangunan Daerah Provinsi Daerah Istimewa Yogyakarta Tahun 2012. Jurnal Profita.

Rudianto. (2012). Pengantar Akuntansi Konsep \& Teknik Penyusunan Laporan Keuangan. In laporan arus kas adalah alat pembayaran yang dimiliki perusahaan dan siap digunakan untuk investasi maupun menjalankan operasi perusahaan setiap saat dibutuhkan.

Sanusi, A. (2014). Teknik Pengumpulan Data Dan Instrumen Penelitian. Metodologi Penelitian.

Sawir, A. (2001). Analisis Kinerja Keuangan dan Perencanaan Keuangan Perusahaan. PT Gramedia Pustaka Utama. https://doi.org/10.1021/j100193a062

Shalahuddin, F. M. (2013). Pengaruh CAR, NPF, BOPO Dan FDR Terhadap Profitabilitas Bank Umum Syariah. Skripsi.

Siamat, D. (2005). Manajemen Lembaga Keuangan. "Kebijakan Moneter Dan Perbankan." In Jakarta: Fakultas Ekonomi Universitas Indonesia, Edisi Kesatu. Https://Doi.Org/10.1515/Ci.2005.27.6.25

Sudarsono, H. (2017). Analisis Pengaruh Kinerja Keuangan Terhadap Profitabilitas Bank Syariah Di Indonesia. $\quad$ Economica: Jurnal Ekonomi Islam. Https://Doi.Org/10.21580/Economica.2017.8.2.1702 
Suharsimi, A. (2010). Prosedur Penelitian: Suatu Pendekatan Praktik (Edisi Revisi). In Jakarta: Rineka Cipta. Https://Doi.Org/10.1017/Cbo9781107415324.004

Sumarlin. (2016). Analisis Pengaruh Inflasi, Car, Fdr, Bopo, Dan Npf Terhadap Profitabilitas Perbankan Syariah. Assets.

Taswan. (2010). Manajemen Perbankan: Konsep, Teknik, Dan Aplikasi. In Yogyakarta: Upp Stim Ykpn Yogyakarta.

Ubaidillah, U. (2017). Analisis Faktor-Faktor Yang Mempengaruhi Profitabilitas Bank Syariah Di Indonesia. $\quad$ El-Jizya : Jurnal Islam. Https://Doi.Org/10.24090/Ej.V4i1.2016.Pp1510188

Ulum, I. (2013). Model Pengukuran Kinerja Intellectual Capital Dengan Ib-Vaic Di Perbankan Syariah. Inferensi. Https://Doi.Org/10.18326/Infsl3.V7i1.185-206

Umar, H. (2008). Metodologi Penelitian Bisnis. In Metode Riset Bisnis.

Wijayani, D. R. (2017). Pengaruh Intellectual Capital Terhadap Kinerja Keuangan Perusahaan Publik Di Indonesia (Studi Empiris Pada Perusahaan Manufaktur di BEI 2012-2014). Jurnal Riset Akuntansi Dan Bisnis Airlangga. https://doi.org/10.31093/jraba.v2i1.23

Wiroso. (2011). Produk Perbankan Syariah Tertinggal. In Lpfe Usakti.

Zulfiah, F., \& Susilowibowo, J. (2014). Pengaruh Inflasi, Bi Rate, Capital Adequacy Ratio (CAR), Non Performing Finance (NPF), Biaya Operasional Dan Pendapatan Operasional (BOPO) Terhadap Profitabilitas Bank Umum Syariah Periode 2008-2012. Jurnal Ilmu Manajemen. 